\title{
Cyclic Adenosine Monophosphate and Diacylglycerol \\ Mutually Inhibitory Second Messengers in Cultured Rat Inner Medullary Collecting Duct Cells
}

Isaac Teitelbaum

With the technical assistance of Alexis Strasheim

Department of Medicine, University of Colorado School of Medicine, Denver, Colorado 80262

\begin{abstract}
Studies were performed to examine interactions between the adenylyl cyclase (AC) and phospholipase C (PLC) signaling systems in cultured rat inner medullary collecting duct cells. Stimulation of AC by either arginine vasopressin (AVP) or forskolin or addition of exogenous cAMP inhibits epidermal growth factor (EGF)-stimulated PLC. This inhibition is mediated by activation of cAMP-dependent kinase as it is prevented by pretreatment with the A-kinase inhibitor, $\mathrm{N}$-[2-(methylamino)ethyl]-5-isoquinoline-sulfonamide (H8) but not by the $\mathrm{C}$-kinase inhibitor, 1-(5-isoquinolinylsulfonyl)2-methylpiperazine (H7). Exposure to EGF eliminates AVPstimulated cAMP generation. This is not mediated by a cyclooxygenase product as inhibition by EGF is observed even in the presence of the cyclooxygenase inhibitor, flurbiprofen. Inhibition by EGF is not due to an increase in inositol trisphosphate $\left(\mathrm{IP}_{3}\right)$ as exposure of saponin-permeabilized cells to exogenous $\mathrm{IP}_{\mathbf{3}}$ is without effect. Inhibition by EGF is prevented by pretreatment with the $\mathrm{C}$-kinase inhibitor, $\mathrm{H7}$, but not by the A-kinase inhibitor, H8. Exposure to the synthetic diacylglycerol (DAG), dioctanoylglycerol, also inhibits AVP-stimulated AC activity; therefore, inhibition by EGF is due to activation of protein kinase $C$. Thus, in cultured rat inner medullary collecting duct cells, cAMP and DAG function as mutually inhibitory second messengers with each impairing formation of the other. (J. Clin. Invest. 1990. 86:46-51.) Key words: adenyl cyclase • phospholipase $\mathrm{C} \bullet$ protein kinase $\mathrm{c} \cdot \mathrm{AVP} \cdot \mathrm{EOF} \bullet$ inner medullary collecting duct
\end{abstract}

\section{Introduction}

One of the major functions of the collecting duct is the stimulation of adenylyl cyclase $(\mathrm{AC})^{1}$ activity in response to arginine vasopressin (AVP). The ensuing increase in cAMP is responsi-

Correspondence and reprint requests to Dr. I. Teitelbaum, C281, University of Colorado School of Medicine, 4200 E. 9th Avenue, Denver, CO 80262.

Received for publication 26 June 1989 and in revised form 26 January 1990

1. Abbreviations used in this paper: AC, adenylyl cyclase; DAG, diacylglycerol; DOG, dioctanoylglycerol; EGF, epidermal growth factor; H7, 1-(5-isoquinolinylsulfonyl)-2-methylpiperazine; H8, $N$-[2-(methylamino)ethyl]-5-isoquinoline-sulfonamide; $\mathrm{IP}_{1}$, inositol monophosphate; $\mathrm{IP}_{2}$, inositol bisphosphate; $\mathrm{IP}_{3}$, inositol trisphosphate; $\mathrm{PLA}_{2}$, phospholipase $A_{2}$; PLC, phospholipase C; RIMCT, rat inner medullary collecting tubule.

J. Clin. Invest.

(c) The American Society for Clinical Investigation, Inc 0021-9738/90/07/0046/06 \$2.00

Volume 86, July $1990,46-51$ ble for mediating the enhanced hydraulic conductivity of the apical membrane. Recent studies from this laboratory have demonstrated that in addition to AC activity, cultured inner medullary collecting duct cells also exhibit hormonal stimulation of phospholipase C (PLC) activity upon exposure to epidermal growth factor (EGF) (1).

It is now well established that AC and PLC are not autonomous in their regulation of cellular events; rather, these two signaling systems may interact in either positive or negative fashion. For example, cAMP has been shown to inhibit phosphoinositide hydrolysis in platelets (2) and neutrophils (3), but it has no effect in monocytes (4). Conversely, activation of protein kinase $\mathrm{C}$, one of the major consequences of phosphoinositide hydrolysis, has been reported to inhibit hormone-stimulated AC activity in some tissues (5-8), while it potentiates AC activity in other tissues (9-12).

Potential interactions between the AC and PLC signaling systems in renal tissues have not been extensively examined. cAMP has been shown to modestly attenuate $\alpha_{1}$-adrenergicstimulated PLC activity in renal cortical slices (13), however, the cell responsible was not identified. Furthermore, the other signaling limb, i.e., the effect of stimulation of PLC on cAMP generation, was not examined. Similarly, while activation of protein kinase $C$ has been shown to inhibit AVP-stimulated water flow in the toad bladder (14) and in the rabbit cortical collecting duct (15), in neither tissue has the effect of cAMP on hormonally stimulated PLC activity been examined. Accordingly, the present study was undertaken to examine bidirectional interactions between the AC and PLC signaling systems in a single cell type, the cultured rat inner medullary collecting tubule (RIMCT) epithelial cell.

\section{Methods}

Cell culture. Cultures of RIMCT cells were prepared as previously described $(1,16)$. For studies on cAMP production, tissue from two rats was used to plate one 24-well dish (Costar Data Packaging Corp., Cambridge, MA); for studies on inositol trisphosphate $\left(\mathrm{IP}_{3}\right)$ production wells were plated at three times this density to obtain uniform confluent cultures.

Generation of samples for measurement of $I P_{3}$. At $96 \mathrm{~h}$ the Hams F12/Liebovitz L15 medium in which the cells were initially grown was aspirated and the cultures washed twice with sterile PBS. The cells were then fed with inositol-free DME supplemented with ${ }^{3} \mathrm{H}$-myo-2-inositol ( $5 \mu \mathrm{Ci}$ /well, Amersham Corp., Arlington Heights, IL). Studies were performed after $24 \mathrm{~h}$ of labeling, as this time has been demonstrated to be sufficient for incorporation into the phospholipid pool. Media was aspirated from the cells and the cells were washed twice with $500 \mu \mathrm{l}$ of PBS. The cells were then incubated for $15 \mathrm{~min}$ in PBS without or with desired test substances, e.g., AVP, forskolin, or CIPheScAMP. In studies employing the protein kinase inhibitors (17) 1-(5-isoquinolinylsulfonyl)-2-methylpiperazine (H7) or $N$-[2-(methylamino)ethyl]-5-isoquinoline-sulfonamide (H8) (Calbiochem-Behring Corp., La Jolla, CA), there was a 5-min preincubation with these compounds alone, 
followed by a 15 -min incubation with these compounds plus any other desired agents.

Upon completion of all preincubations, the buffer was aspirated and replaced with $500 \mu \mathrm{l}$ of PBS without or with $100 \mathrm{nM}$ EGF (Sigma Chemical Co., St. Louis, MO). Previous studies have demonstrated that EGF-stimulated $\mathrm{IP}_{3}$ production in RIMCT cells peaks at $10 \mathrm{~s}(1)$. Therefore, the reaction was terminated after $10 \mathrm{~s}$ by the addition of 500 $\mu \mathrm{l}$ of ice-cold $20 \%$ TCA. The cells were scraped off of the dish and centrifuged at $1,000 \mathrm{~g}$ for $10 \mathrm{~min}$. The supernate containing inositol phosphates was washed four times with an equal volume of ether and stored at $-20^{\circ} \mathrm{C}$ until analysis'

Determination of inositol phosphates. Inositol phosphates were separated by anion exchange chromatography as described by Berridge et al. (18). In brief, the samples were thawed and brought to a pH of 6.0 or greater with $50 \mathrm{mM}$ Tris base. They were then applied to Dowex $1 \mathrm{x}-8$ columns (formate form) (Dow Corning Corp., Midland, MI). Serial elutions were performed with water, $5 \mathrm{mM}$ sodium tetraborate $/ 60 \mathrm{mM}$ sodium formate, $0.1 \mathrm{M}$ formic acid/0.2 $\mathrm{M}$ ammonium formate, $0.1 \mathrm{M}$ formic acid/0.4 M ammonium formate, and 0.1 $\mathrm{M}$ formic acid/1.0 M ammonium formate which elute, respectively, inositol, glycerylphosphorylinositol, inositol phosphate, inositol bisphosphate (IP $\left.{ }_{2}\right)$, and $\mathrm{IP}_{3}$. Results are expressed as counts per minute of $\mathrm{IP}_{3}$ per well.

Determination of DAG levels. At $96 \mathrm{~h}$ after plating cells were fed with Ham's/Leibovitz medium containing $\left[{ }^{14} \mathrm{C}\right]$ arachidonic acid $(6$ $\mu \mathrm{Ci} / \mathrm{ml}$ ) and $5 \%$ fetal calf serum. After $16-18 \mathrm{~h}$ the medium was aspirated and cells were washed twice with PBS. Cells were exposed to PBS containing the desired test substances for $15 \mathrm{~min}$; PBS was aspirated and the cells scraped into $1 \mathrm{ml}$ of ice-cold methanol under $\mathrm{N}_{2}$. After $60 \mathrm{~min}$ at $4^{\circ} \mathrm{C} 2 \mathrm{ml}$ of ice-cold chloroform was added, the cells were sonicated, gassed with $\mathrm{N}_{2}$, and extracted overnight at $4^{\circ} \mathrm{C} .750 \mu \mathrm{l}$ of $\mathrm{H}_{2} \mathrm{O}$ was added, samples were vortexed for 2-3 min, then centrifuged at 1,200 rpm for $6 \mathrm{~min}$. The lower phase that contained lipids was aspirated, dried under $\mathrm{N}_{2}$, and resuspended in $50 \mu \mathrm{l}$ of chloroform/methanol, 2:1.

Samples were spotted on to standard silica plates and subjected to thin layer chromatography using a petroleum ether/diethyl ether/glacial acetic acid (70:30:1) solvent system. The plates were subjected to autoradiography and the diacylglycerol (DAG) containing bands were scraped and quantitated by liquid scintillation counting (19). DAG was expressed as a percentage of total phospholipids.

Determination of cAMP production. Studies were performed in Krebs-Ringer's buffer, $\mathrm{pH} 7.4$, at $300 \mathrm{mos} \mathrm{M} / \mathrm{kg} \mathrm{H}_{2} \mathrm{O}$ in the presence of $0.5 \mathrm{mM}$ isobutylmethylxanthine to inhibit phosphodiesterase. Studies using exogenous $\mathrm{IP}_{3}$ require cell permeabilization. These studies were performed in a buffer designed to simulate the intracellular milieu (composition in millimoles: $20 \mathrm{NaCl}, 100 \mathrm{KCl}, 5 \mathrm{Mg}$ sulfate, 1 $\mathrm{NaH}_{2} \mathrm{PO}_{4}, 25 \mathrm{Na}$ bicarbonate, and 1.0 EGTA, pH 7.2) containing saponin $(50 \mu \mathrm{g} / \mathrm{ml})$. Incubation with effector solutions and subsequent determinations of CAMP and protein were performed as reported previously $(16,20)$. Results are expressed as femtomoles cAMP per microgram protein.

Statistical analysis. In studies on cAMP production, values obtained in triplicate wells were meaned for an $n$ of one; in studies on $\mathrm{IP}_{3}$ or DAG production each well was considered an $n$ of one. Comparisons between two treatment groups were by the unpaired $t$ test. Comparisons between three or more treatment groups were done by oneway analysis of variance (ANOVA) followed by appropriate contrasts of a priori assumptions (21). In all circumstances $P<0.05$ was considered significant. Data are presented as mean \pm SEM.

\section{Results}

Effect of CAMP on EGF-stimulated PLC activity. The effect of cAMP on EGF-stimulated $\mathrm{IP}_{\mathbf{3}}$ production is portrayed in Fig. 1. EGF significantly increases $\mathrm{IP}_{3}$ production from $975 \pm 102$ to $2,371 \pm 63 \mathrm{cpm} /$ well $(P<0.001)$. Stimulation by EGF is not observed in cells pretreated with $100 \mathrm{nM}$ AVP $(1,024 \pm 158)$,

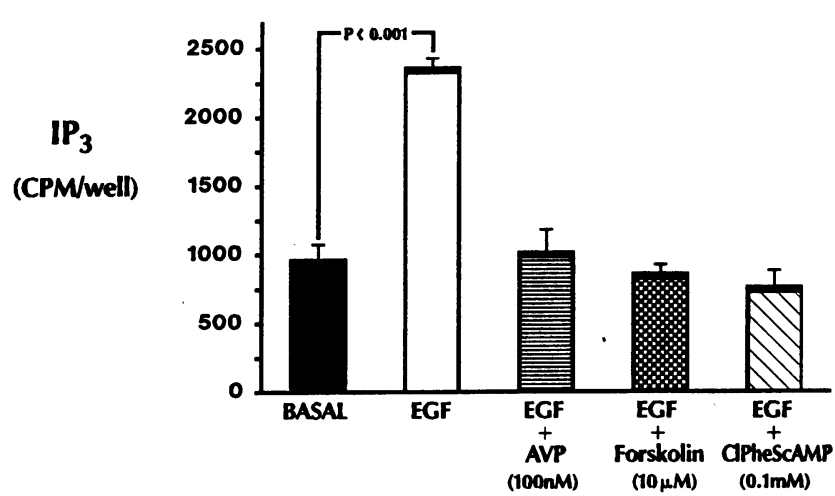

Figure 1. Effect of cAMP on epidermal growth factor (EGF)-stimulated $\mathrm{IP}_{3}$ production $(n=4)$. Cells are exposed to AVP, forskolin, or ClPheScAMP for 15 min before a 10-s incubation with $100 \mathrm{nM}$ EGF. Exposure to cAMP prevents stimulation by EGF.

$10 \mu \mathrm{M}$ forskolin $(868 \pm 57)$, or $0.1 \mathrm{mM}$ ClPheScAMP (774 \pm 108$)$. Pretreatment with CIPheScAMP results in a decrease in inositol monophosphate $\left(\mathrm{IP}_{1}\right)(1,658 \pm 169$ vs. $893 \pm 149 \mathrm{cpm} /$ well; $n=4, P<0.02)$ and $\mathrm{IP}_{2}(906 \pm 142$ vs. $513 \pm 49 \mathrm{cpm} /$ well; $n=4, P<0.05$ ) as well. Similarly, as seen in Fig. 2, pretreatment with CIPheScAMP decreases EGFstimulated DAG production from $4.20 \pm 0.48$ to $2.85 \pm 0.04 \%$ of total phospholipid ( $n=3 ; P<0.05$ ). Thus cAMP, whether added exogenously or stimulated endogenously, inhibits subsequent stimulation of PLC.

Mechanism of inhibition by cAMP. To determine whether the effect of CAMP is mediated by stimulation of protein kinase $A$, the effect of $\mathrm{H} 8$, a relatively specific inhibitor of cyclic nucleotide-dependent kinases (17), was examined. As seen in Fig. 3, $50 \mu \mathrm{M}$ H8 itself has no effect on subsequent EGF-stimulated $\mathrm{IP}_{3}$ production. However, inhibition of PLC activity by ClPheScAMP is not observed in the presence of $\mathrm{H8}$ $(2,124 \pm 158$ vs. $2,183 \pm 162$, NS). In contrast, $H 7$, a relatively selective inhibitor of protein kinase $C(17)$, which itself has no effect on EGF-stimulated $\mathrm{IP}_{3}$ production, fails to prevent inhibition by ClPheScAMP $(2,206 \pm 115$ vs. $842 \pm 109, P<0.001)$. This indicates that inhibition of EGF-stimulated PLC activity by cAMP is mediated by activation of A-kinase.

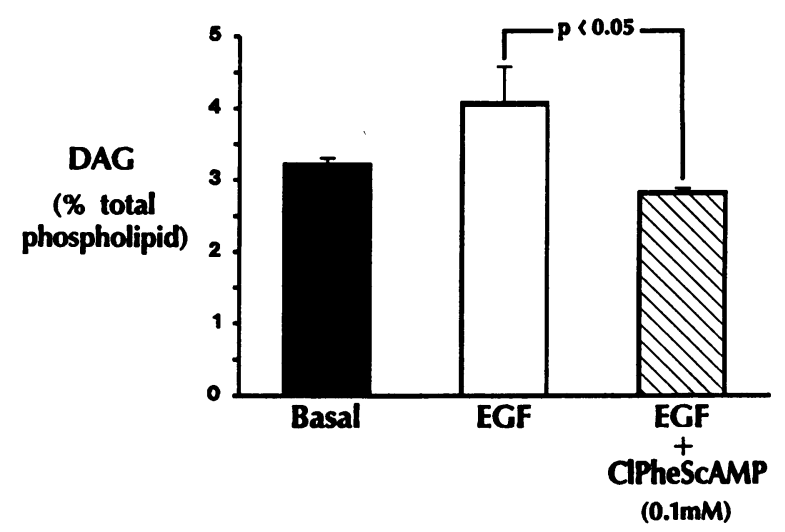

Figure 2. Effect of cAMP on EGF-stimulated DAG production ( $n$ = 3). Cells are exposed to CIPheScAMP for $15 \mathrm{~min}$ before and during incubation with EGF. CIPheScAMP inhibits EGF-stimulated DAG production. 


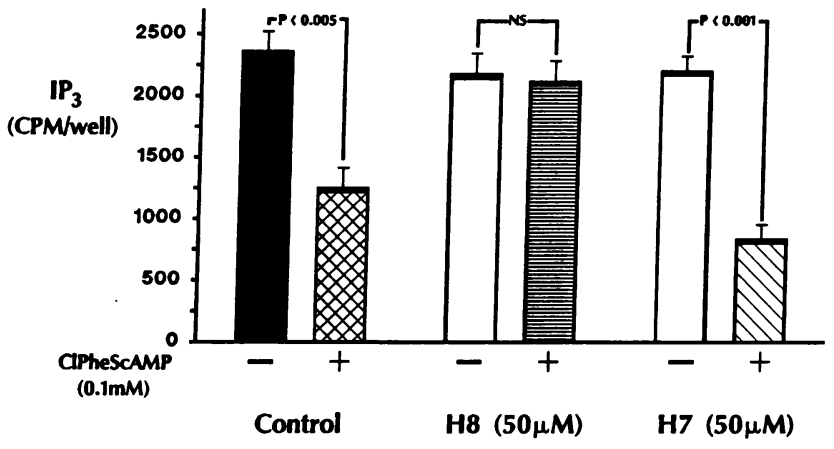

Figure 3. Effect of protein kinase inhibitors on cAMP inhibition of PLC $(n=4)$. Cells are exposed to $\mathrm{H} 7$ or $\mathrm{H} 8$ for $5 \mathrm{~min}$ before and during exposure to ClPheScAMP. Pretreatment with H8, but not with $\mathrm{H} 7$, prevents inhibition by cAMP.

Effect of stimulation of PLC on AVP-stimulated AC activity. The effect of EGF on basal and AVP-stimulated cAMP accumulation is depicted in Fig. 4. EGF has no effect on basal cAMP accumulation; however, simultaneous addition of EGF eliminates the response to either a submaximal $\left(10^{-9} \mathrm{M}\right.$, $56.2 \pm 3.30$ vs. $28.92 \pm 3.14 \mathrm{fmol} / \mu$ g protein, $P<0.001)$ or a maximal $\left(10^{-7} \mathrm{M}, 151.15 \pm 23.32\right.$ vs. $\left.37.05 \pm 4.91, P<0.001\right)$ concentration of AVP.

Though all studies were performed with $100 \mathrm{nM}$ EGF, AVP-stimulated AC activity was, in fact, inhibited at much lower concentrations of EGF. As seen in Fig. 5, inhibition by EGF was observed at a concentration as low as $0.1 \mathrm{nM}$ with a calculated $\mathrm{IC}_{50}$ of $0.93 \mathrm{nM}$. AVP-stimulated AC activity was completely inhibited by 5 nM EGF.

Mechanism of inhibition by EGF. In addition to stimulating PLC, EGF also stimulates phospholipase $\mathrm{A}_{2}\left(\mathrm{PLA}_{2}\right)$ in RIMCT cells with resultant $\mathrm{PGE}_{2}$ production (22). $\mathrm{PGE}_{2}$ has been suggested to inhibit $\mathrm{AC}$ in the rabbit cortical collecting duct (23). Stimulation of PLC results in the formation of DAG and $\mathrm{IP}_{3} . \mathrm{IP}_{3}$ increases cytosolic $\mathrm{Ca}^{2+}$ by releasing $\mathrm{Ca}^{2+}$ from nonmitochondrial pools (24). DAG activates protein kinase $C$ (25). Previous studies have demonstrated inhibition of AVPstimulated CAMP accumulation $(16,26)$ or water flux $(27)$ upon increasing cytosolic $\mathrm{Ca}^{2+}$. Activation of protein kinase $\mathrm{C}$ is known to inhibit stimulation of $\mathrm{AC}$ in a variety of tissues (5-8). Studies were undertaken, therefore, to determine which of these second messengers, $\mathrm{PGE}_{2}, \mathrm{IP}_{3}$, or DAG, mediates EGF inhibition of AVP-stimulated AC activity.

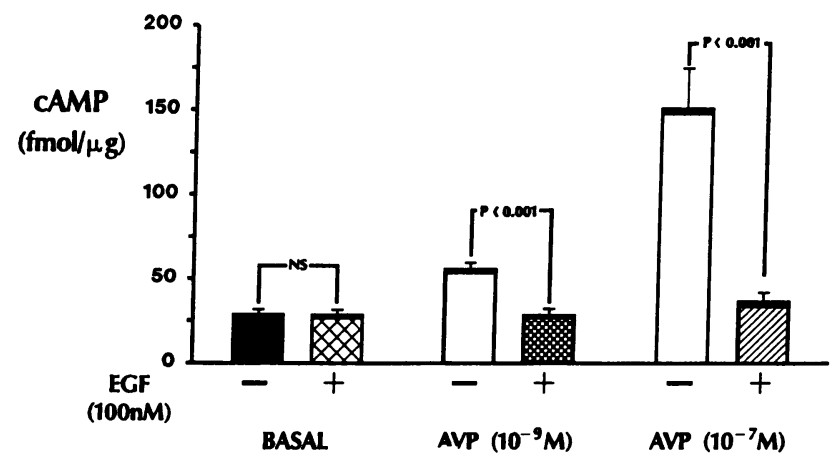

Figure 4. Effect of EGF on AVP-stimulated cAMP generation ( $n$ $=6)$. EGF $(100 \mathrm{nM})$ is added simultaneously with AVP. Exposure to EGF eliminates AVP-stimulated cAMP generation.

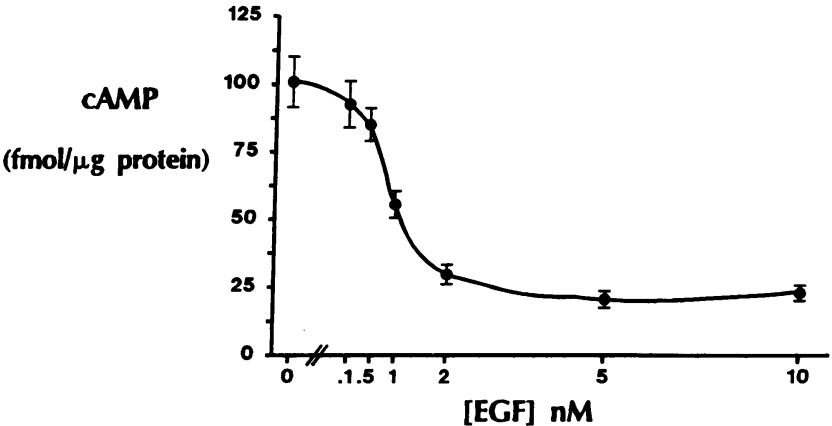

Figure 5. Dose-response curve for inhibition of AVP-stimulated cAMP generation by EGF $(n=3)$. The indicated concentration of EGF is added simultaneously with $10^{-7} \mathrm{M}$ AVP.

The role of $P G E_{2}$. To examine a potential role for EGFstimulated $\mathrm{PGE}_{2}$ production in mediating inhibition of $\mathrm{AC}$, the effect of EGF was examined in the presence of the cyclooxygenase inhibitor, flurbiprofen (5 $\mu \mathrm{M}$; Sigma Chemical Co.), which inhibits ionomycin-stimulated $\mathrm{PGE}_{2}$ production $>95 \%$ (1). Inhibition of AC by EGF is not mediated by a cyclooxygenase product as even in the presence of flurbiprofen, EGF eliminates the response to $10^{-7} \mathrm{M}$ AVP $(156.27 \pm 27.05$ vs. $38.9 \pm 10.20 \mathrm{fmol} / \mu \mathrm{g}$ protein; $n=3, P$ $<0.02)$.

The role of $I P_{3}$. RIMCT cells were permeabilized with saponin as described above and the ability of AVP to stimulate cAMP accumulation was assessed in the absence or presence of $10 \mu \mathrm{M} \mathrm{IP}$. Saponization itself had no effect on AC, as AVP still increased cAMP accumulation from $58.19 \pm 4.94$ to $146.10 \pm 24.57 \mathrm{fmol} / \mu \mathrm{g}$ protein $(n=5 ; P<0.01)$. Exposure to $\mathrm{IP}_{3}$ had no effect on either basal (49.47 \pm 4.87 vs. $58.18 \pm 4.94 ; n$ $=5, \mathrm{NS})$ or AVP-stimulated cAMP accumulation (166.15 \pm 28.76 vs. $146.10 \pm 24.57 ; n=5$, NS). Therefore, inhibition of AVP-stimulated AC activity by EGF was not a consequence of an $\mathrm{IP}_{3}$-induced increase in cytosolic $\mathrm{Ca}^{2+}$.

The role of $D A G$. To examine a potential role for a DAGmediated increase in the activity of protein kinase $C$ in inhibition of AC by EGF, the effect of protein kinase $C$ inhibition was examined. As seen in the upper panel of Fig. 6, pretreatment with the $\mathrm{C}$-kinase inhibitor, $\mathrm{H} 7$, prevented inhibition of AVP-stimulated AC activity by EGF. In contrast, in a separate set of experiments shown in the lower panel of Fig. 6, the A-kinase inhibitor, $\mathrm{H8}$, conferred no protection against inhibition by EGF.

To confirm that activation of protein kinase $C$ results in . inhibition of AVP-stimulated AC activity, the effect of the synthetic highly permeable compound $s n$-1,2-dioctanoylglycerol (DOG) (28) was examined. As shown in Fig. 7, simultaneous addition of $100 \mathrm{nM}$ DOG inhibited AVP-stimulated AC activity from $100.89 \pm 9.33$ to $58.29 \pm 2.71$ ( $n=3, P<0.02$ ). Inhibition by DOG was not observed in cells pretreated with H7, as AVP-stimulated cAMP generation remained at $100.08 \pm 7.03 \mathrm{fmol} / \mu \mathrm{g}$ even upon exposure to DOG.

\section{Discussion}

The role of phosphoinositide hydrolysis in the function of the collecting duct and its potential interactions with AC have not 

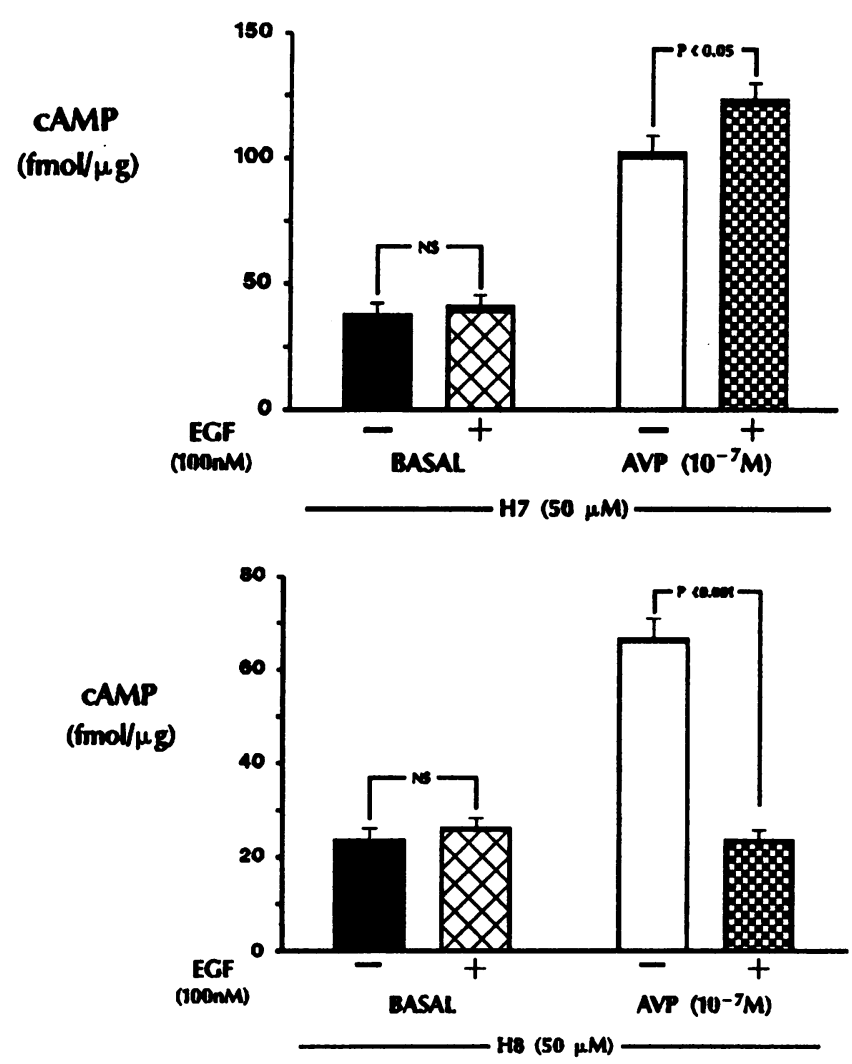

Figure 6. Effect of protein kinase inhibitors on EGF-inhibition of AC. Cells are exposed to $\mathrm{H} 7$ (top, $n=6$ ) or $\mathrm{H8}$ (bottom, $n=5$ ) for 5 min before and during incubation without or with EGF. H7 prevents inhibition by EGF; $\mathrm{H} 8$ does not.

been fully defined. Bradykinin has been shown to stimulate PLC in cultured rabbit papillary duct cells (29) but potential interactions with the AC signaling system were not examined. Recent studies from this laboratory have demonstrated EGFstimulated phosphoinositide hydrolysis in the cultured rat inner medullary collecting duct (1). The data reported herein are the first to describe communication between the AC and

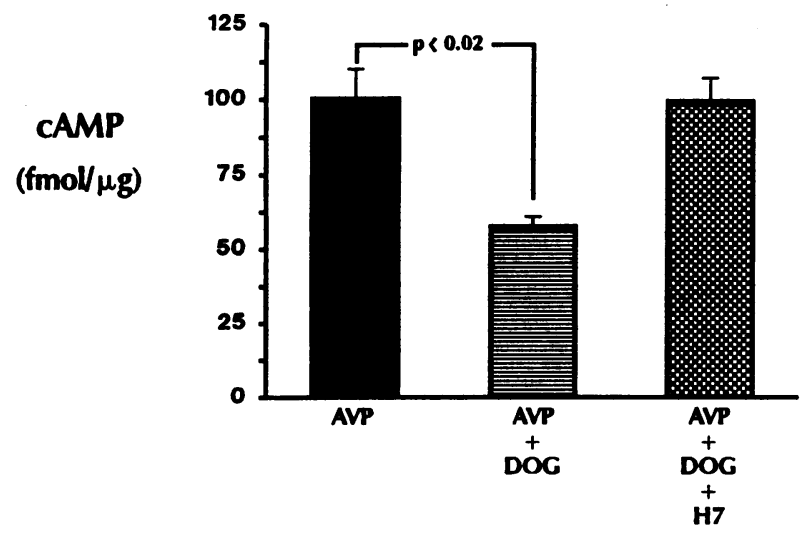

Figure 7. Effect of DOG on AVP-stimulated cAMP generation ( $n$ =3). DOG (100 nM) was added simultaneously with $10^{-7} \mathrm{M} \mathrm{AVP;}$ H7 was present for $5 \mathrm{~min}$ before incubation with DOG. DOG inhibited AVP-stimulated cAMP generation; inhibition was not observed in the presence of $\mathrm{H} 7$.
PLC signaling systems in a single renal cell type with a product of each system inhibiting function of the other.

Stimulation of AC by either AVP or forskolin or the provision of exogenous cAMP all result in a decrease in EGF-stimulated $\mathrm{IP}_{3}$ production (Fig. 1). It has been suggested that production of DAG, the endogenous activator of protein kinase $C$, may result not only from the hydrolysis of polyphosphoinositides but of other phospholipids (e.g., phosphatidylcholine) as well (30). It is important to note, therefore, that pretreatment with ClPheScAMP inhibits EGF-stimulated DAG production (Fig. 2) as well as $\mathrm{IP}_{3}$ formation. While the source of the DAG is unknown, it is clear that inhibition of PLC by cAMP results in a decrease in the levels of both second messengers, $\mathrm{IP}_{3}$ and DAG. The exact locus of inhibition by cAMP is not known. However, it is likely that cAMP decreases $\mathrm{IP}_{3}$ levels by impairing the formation of $\mathrm{IP}_{3}$ rather than by enhancing its degradation, as the levels of $\mathrm{IP}_{1}$ and $\mathrm{IP}_{2}$ are also decreased. The decrease in PLC activity upon exposure to cAMP is a consequence of an A-kinase-mediated phosphorylation event as inhibition by CAMP is not observed in the presence of the A-kinase inhibitor, $\mathrm{H} 8$ (Fig. 3). Although the $K_{\mathrm{i}}$ of $\mathrm{H} 8$ for cAMP-dependent protein kinase is only modestly lower than that of $\mathrm{H} 7(1.2$ vs. $3.0 \mu \mathrm{M})(17)$, the specificity of $\mathrm{H} 8$ for A-kinase is demonstrated by the inability of $\mathrm{H} 7$ to prevent inhibition of PLC by CAMP. Conversely, inhibition of AC by DOG, which is known to function by activation of protein kinase $\mathrm{C}$, is prevented by $\mathrm{H} 7$ but not by $\mathrm{H} 8$ despite the only modest difference in their respective $K_{\mathrm{i}} \mathrm{s}$ for protein kinase C (6.0 vs. $15.0 \mu \mathrm{M})$.

Similar to its ability to inhibit PLC, cAMP has also been

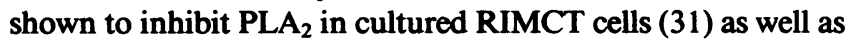
other tissues $(32,33)$. The concentration of ClPheScAMP that inhibits PLC (0.1 mM) is the same as that which inhibits PLA in this same tissue (31) and is comparable to that which stimulates water flux in the toad bladder (34).

Exposing RIMCT cells to AVP in the presence of EGF results in abolition of AVP-stimulated cAMP generation (Fig. 4). As EGF eliminates the response to AVP even in the background of cyclooxygenase inhibition, it is clear that the effect of EGF is not a consequence of its stimulation of $\mathrm{PGE}_{2}$ production (22). This is in accord with previous studies in RIMCT cells that do not support an inhibitory effect of $\mathrm{PGE}_{2}$ on $\mathrm{AC}$ in this tissue. Sato and Dunn have reported that $\mathrm{PGE}_{2}$ at a high concentration enhances cAMP accumulation in RIMCT cells but observed no inhibition at any concentration (35). Similarly, previous studies from this laboratory have shown that in RIMCT cells exposed to the calcium ionophore A23187, which very potently stimulates $\mathrm{PGE}_{2}$ production, AVP-stimulated cAMP accumulation is not enhanced upon inhibition of cyclooxygenase with meclofenamate (16).

Studies were then performed to determine whether one of the second messengers produced upon stimulation of PLC in response to $\mathrm{EGF}, \mathrm{IP}_{3}$ or $\mathrm{DAG}$, is responsible for mediating inhibition of $\mathrm{AC}$ by EGF. Exposure of saponin-permeabilized cells to exogenous $\mathrm{IP}_{3}$ had no effect on AVP-stimulated cAMP accumulation. Release of $\mathrm{Ca}^{2+}$ from cellular stores has been reported to occur in response to the concentration of $\operatorname{IP}_{3}(10$ $\mu \mathrm{M})$ used in this study $(36,37)$. The magnitude of the increase in cytosolic $\mathrm{Ca}^{2+}$ in response to $\mathrm{IP}_{3}$ in RIMCT cells was not determined. Therefore, the present study does not unequivocally exclude a role for $\mathrm{Ca}^{2+}$ in mediating inhibition by EGF. 
However, as inhibition of protein kinase $\mathrm{C}$ (see below) results in complete restoration of AVP-responsiveness in the presence of EGF, the role of any other mediator is likely to be minimal. The lack of inhibition by $\mathrm{IP}_{3}$ differs from previous studies in the collecting duct in which increased cytosolic $\mathrm{Ca}^{2+}$ inhibited the response to $\operatorname{AVP}(16,27)$. This most likely reflects the fact that the amount of $\mathrm{Ca}^{2+}$ released by $\mathrm{IP}_{3}$ and, therefore, the subsequent increase in cytosolic $\mathrm{Ca}^{2+}$ is much less than that obtained with a calcium ionophore $(36,37)$, as had been employed in earlier studies $(16,27)$.

Rather than an effect of $\mathrm{IP}_{3}$, inhibition of $\mathrm{AC}$ by EGF appears to be due to activation of protein kinase $\mathrm{C}$ as $\mathrm{EGF}$ has no effect in the presence of the C-kinase inhibitor, H7 (Fig. 6). We have previously reported that EGF-stimulated $\mathrm{IP}_{3}$ production in RIMCT cells is first detected at $10 \mathrm{nM}$ EGF (1). Yet, as seen in Fig. 5, inhibition of AVP-stimulated AC activity is observed with as little as $0.1 \mathrm{nM}$ EGF and is complete at $5 \mathrm{nM}$. As activation of PLC results in hydrolysis of not only phosphatidylinositol bisphosphate but of phosphatidylinositol monophosphate and phosphatidylinositol as well (and perhaps other phospholipids, e.g., phosphatidylcholine) production of DAG, on a molar basis, is likely to exceed production of $\mathrm{IP}_{\mathbf{3}}$ (30). Therefore, inhibition of AC by concentrations of EGF below the threshold for detection of $\mathrm{IP}_{3}$ production itself suggests that the inhibition is a consequence of DAG production.

Activation of protein kinase $C$ has been shown to inhibit AVP-stimulated water flow in the toad bladder (14) and in the isolated perfused rabbit cortical collecting tubule (15). Though a pre-cAMP site appears operant in the toad bladder (14), the predominant site of action of protein kinase $\mathrm{C}$ in both tissues is post-cAMP. Likewise, the ability of EGF to inhibit AVP- and cAMP-stimulated water flux in the rabbit cortical collecting tubule to a similar extent (38) suggests a predominantly postcAMP site of action. The studies reported herein demonstrate that, apart from any post-cAMP effects, EGF, via activation of protein kinase $C$, profoundly inhibits the generation of $\mathrm{CAMP}$ in response to AVP. This finding is consistent with other studies that have shown protein kinase C-mediated inhibition of AVP-stimulated AC activity in Madin-Darby canine kidney cells (39) or cultured rabbit cortical collecting ducts (40). However, in marked contrast to those studies in which inhibition of AC is observed only after more prolonged exposure (15 min to $6 \mathrm{~h})$ to activators of protein kinase $C$, in the present study inhibition by EGF or DOG requires no preincubation but is observed upon addition of these agents simultaneously with AVP. This indicates a direct inhibitory effect of protein kinase $C$ rather than one mediated by a secondary phenomenon such as stimulation of cell proliferation, as had been previously suggested (40). Furthermore, unlike the other studies in which activation of protein kinase $\mathrm{C}$ attenuates but does not eliminate AVP-stimulated cAMP generation, exposure of RIMCT cells to EGF abolishes the response to AVP. DOG is less potent an inhibitor of $\mathrm{AC}$, perhaps reflecting the need for permeation of the cell membrane. Finally, in none of the previous studies on the effect of protein kinase $\mathrm{C}$ was the other signaling limb, i.e., the effect of cAMP on phosphoinositide hydrolysis, examined.

The physiologic correlates of the biochemical observations described herein require further examination. As the role of phosphoinositide hydrolysis in the function of the collecting duct is itself unclear, one can only speculate upon the significance of its modulation by cAMP. In contrast, the profound

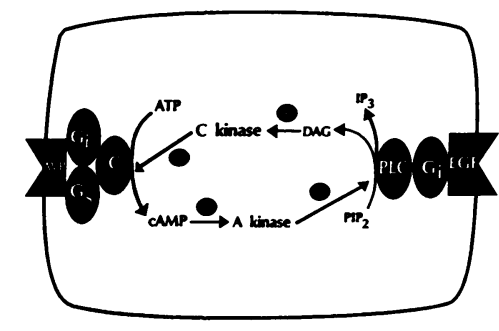

Figure 8. Schematic representation of the interactions between the $\mathrm{AC}$ and PLC signaling systems in the cultured rat inner medullary collecting duct.

inhibition of AVP-stimulated cAMP generation by activation of protein kinase $C$ suggests a possible role for protein kinase $C$ in "turn off" of the AVP signal.

In summary, the data presented herein demonstrate for the first time the existence of this bidirectional signaling system in cultured inner medullary collecting tubule cells (Fig. 8). Stimulation of $\mathrm{AC}$ results in the formation of cAMP which, via activation of A-kinase, inhibits PLC; conversely, stimulation of PLC results in the formation of DAG which, via activation of C-kinase, inhibits AC. The exact loci of inhibition by these respective kinases remain to be determined.

\section{Acknowledgments}

The author would like to thank Mr. Douglas Holmes and Dr. Stewart A. Metz for assistance with the determination of DAG levels, and Ms. Linda M. Benson for expert secretarial assistance.

This work was supported by grant DK-38464 from the National Institutes of Health.

\section{References}

1. Teitelbaum, I., A. Strasheim, and T. Berl. 1990. Epidermal growth factor-stimulated phosphoinositide hydrolysis in rat inner medullary collecting tubule cells. Regulation by $\mathbf{G}$ protein, calcium, and protein kinase C. J. Clin. Invest. 85:1044-1050.

2. Takai, Y., K. Kaibuchi, K. Sano, and Y. Nishizuka. 1982. Counteraction of calcium-activated, phospholipid-dependent protein kinase activation by adenosine 3 ',5'-monophosphate and guanosine $3^{\prime}, 5^{\prime}$ monophosphate in platelets. J. Biochem. (Tokyo). 91:403-406.

3. Bianca, V. D., P. De Togni, M. Grezeskowiak, L. M. Vicentini, and F. Di Virgilio. 1986. Cyclic AMP inhibition of phosphoinositide turnover in human neutrophils. Biochim. Biophys. Acta. 886:441-447.

4. Godfrey, R. W., R. M. Manzi, D. E. Gennaro, and S. T. Hoffstein. 1987. Phospholipid and arachidonic acid metabolism in zymosan-stimulated human monocytes: modulation by cAMP. J. Cell. Physiol. 131:384-392.

5. Beckner, S. K., and W. L. Farrar. 1987. Inhibition of adenylate cyclase by IL 2 in human T lymphocytes is mediated by protein kinase C. Biochem. Biophys. Res. Commun. 145:176-182.

6. Williams, K. A., W. Murphy, and R. J. Haslam. 1987. Effects of activation of protein kinase $C$ on the agonist-induced stimulation and inhibition of cyclic AMP formation in intact human platelets. Biochem. J. 243:667-678.

7. Hollingsworth, E. B., and J. W. Daly. 1987. Inhibition of receptor-mediated stimulation of cyclic AMP accumulation in neuroblastoma-hybrid NCB-20 cells by a phorbol ester. Biochim. Biophys. Acta. 930:272-278.

8. Yamashita, A., T. Kurokawa, Y. Une, and S. Ishibashi. 1988. Phorbol ester regulates stimulatory and inhibitory pathways of the hormone-sensitive adenylate cyclase system in rat reticulocytes. Eur. J. Pharmacol. 151:167-175.

9. Magnaldo, I., J. Pouysségur, and S. Paris. 1988. Thrombin exerts a dual effect on stimulated adenylate cyclase in hamster fibroblasts, an 
inhibition via a GTP-binding protein and a potentiation via activation of protein kinase C. Biochem. J. 253:711-719.

10. Phaneuf, S., P. Berta, C. Le Peuch, J. Haiech, and J.-C. Cavadore. 1988. Phorbol ester modulation of cyclic AMP accumulation in a primary culture of rat aortic smooth muscle cells. J. Pharmacol. Exp. Ther. 245:1042-1047.

11. Chambaut-Guerin, A.-M., and P. Thomopoulos. 1987. Protein kinase $C$ potentiates isoproterenol-mediated cyclic AMP production without modifying the homologous desensitization process in $\mathbf{J 7 7 4}$ cells. Eur. J. Biochem. 170:381-387.

12. Summers, S. T., J. M. Walker, J. J. Sando, and M. J. Cronin. 1988. Phorbol esters increase adenylate cyclase activity and stability in pituitary membranes. Biochem. Biophys. Res. Commun. 151:16-24.

13. Neylon, C. B., and R. J. Summers. 1988. Inhibition by cAMP of the phosphoinositide response to $\alpha_{1}$-adrenoceptor stimulation in rat kidney. Eur. J. Pharmacol. 148:441-444.

14. Schlondorff, D., and S. D. Levine. 1985. Inhibition of vasopressin-stimulated water flow in toad bladder by phorbol myristate acetate, dioctanoylglycerol, and RHC-80267. J. Clin. Invest. 76:10711078.

15. Ando, Y., H. R. Jacobson, and M. D. Breyer. 1987. Phorbol myristate acetate, dioctanoylglycerol, and phosphatidic acid inhibit the hydroosmotic effect of vasopressin on rabbit cortical collecting tubule. J. Clin. Invest. 80:590-593.

16. Teitelbaum, I., and T. Berl. 1986. Effects of calcium on vasopressin-mediated cyclic adenosine monophosphate formation in cultured rat inner medullary collecting tubule cells. Evidence for the role of intracellular calcium. J. Clin. Invest. 77:1574-1583.

17. Hidaka, H., M. Inagaki, S. Kawamoto, and Y. Sasaki. 1984. Isoquinolinesulfonamides, novel and potent inhibitors of cyclic nucleotide dependent protein kinase and protein kinase C. Biochemistry. 23:5036-5041.

18. Berridge, M. J., R. M. C. Dawson, C. P. Downes, J. P. Heslop, and R. F. Irvine. 1983. Changes in the levels of inositol phosphates after agonist-dependent hydrolysis of membrane phosphoinositides. Biochem. J. 212:473-482.

19. Dunlop, M., and S. A. Metz. 1989. A phospholipase D-like mechanism in pancreatic islet cells: stimulation by calcium ionophore, phorbol ester and sodium fluoride. Biochem. Biophys. Res. Commun. 163:922-928.

20. Teitelbaum, I., A. Strasheim, and T. Berl. 1989. Adrenergic control of cAMP generation in rat inner medullary collecting tubule cells. Kidney Int. 35:647-653.

21. 1980. Statistical Methods. G. W. Snedecor and W. G. Cochran, editors. 7th ed. Iowa State University Press, Ames, IA. 224-226.

22. Teitelbaum, I. 1990. The epidermal growth factor receptor is coupled to a phospholipase $A_{2}$-specific pertussis toxin-inhibitable guanine nucleotide-binding regulatory protein in cultured rat inner medullary collecting tubule cells. J. Biol. Chem. 265:4218-4222.

23. Nadler, S. P., S. C. Hebert, and B. M. Brenner. 1986. PGE $_{2}$, forskolin, and cholera toxin interactions in rabbit cortical collecting tubule. Am. J. Physiol. 250:F126-F136.
24. Berridge, M. J., and R. F. Irvine. 1984. Inositol trisphosphate, a novel second messenger in cellular signal transduction. Nature (Lond.). 312:315-321.

25. Nishizuka, Y. 1986. Studies and perspectives of protein kinase C. Science (Wash. DC). 233:305-312.

26. Takaichi, K., and K. Kurokawa. 1988. Inhibitory guanosine triphosphate-binding protein-mediated regulation of vasopressin action in isolated single medullary tubules of mouse kidney. J. Clin. Invest. 82:1437-1444.

27. Jones, S. M., G. Frindt, and E. E. Windhager. 1988. Effect of peritubular [Ca] or ionomycin on hydrosmotic response of CCTs to ADH or cAMP. Am. J. Physiol. 254:F240-F253.

28. Davis, R. J., B. R. Ganong, R. M. Bell, and M. P. Czech. 1985. $s n-1,2-D i o c t a n o y l g l y c e r o l$. A cell-permeable diacylglycerol that mimics phorbol diester action on the epidermal growth factor receptor and mitogenesis. J. Biol. Chem. 260:1562-1566.

29. Shayman, J. A., and A. R. Morrison. 1985. Bradykinin-induced changes in phosphatidyl inositol turnover in cultured rabbit papillary collecting tubule cells. J. Clin. Invest. 76:978-984.

30. Exton, J. H. 1988. Mechanisms of action of calcium-mobilizing agonists: some variations on a young theme. FASEB (Fed. Am. Soc. Exp. Biol.) J. 2:2670-2676.

31. Teitelbaum, I., J. N. Mansour, and T. Berl. 1986. Effect of cAMP on prostaglandin $E_{2}$ production in cultured rat inner medullary collecting tubule cells. Am. J. Physiol. 251:F671-F677.

32. Schlondorff, D., and J. A. Satriano. 1985. Interactions of vasopressin, cAMP, and prostaglandins in toad urinary bladder. Am. J. Physiol. 248:F454-F458.

33. Hassid, A. 1983. Inhibition of prostaglandin biosynthesis in renal (MDCK) cells by cAMP. Am. J. Physiol. 244:C369-C376.

34. Orloff, J., and J. S. Handler. 1962. The similarity of effects of vasopressin, adenosine-3,5-phosphate (cyclic AMP) and theophylline on the toad bladder. J. Clin. Invest. 41:702-709.

35. Sato, M., and M. J. Dunn. 1984. Interactions of vasopressin, prostaglandins, and cAMP in rat renal papillary collecting tubule cells in culture. Am. J. Physiol. 247:F423-F433.

36. Suematsu, E., M. Hirata, T. Hashimoto, and H. Kuriyama. 1984. Inositol 1,4,5-trisphosphate releases $\mathrm{Ca}^{2+}$ from intracellular store sites in skinned single cells of porcine coronary artery. Biochem. Biophys. Res. Commun. 120:481-485.

37. Chueh, S.-H., and D. L. Gill. 1986. Inositol 1,4,5-trisphosphate and guanine nucleotides activate calcium release from endoplasmic reticulum via distinct mechanisms. J. Biol. Chem. 261:13883-13886.

38. Breyer, M. D., H. R. Jacobson, and J. A. Breyer. 1988. Epidermal growth factor inhibits the hydroosmotic effect of vasopressin in the isolated perfused rabbit cortical collecting tubule. J. Clin. Invest. 82:1313-1320.

39. Friedlander, G., and C. Amiel. 1987. Protein kinase C activators and bradykinin selectively inhibit vasopressin-stimulated cAMP synthesis in MDCK cells. Biochim. Biophys. Acta. 929:311-317.

40. Dixon, B. S., R. Breckon, C. Burke, and R. J. Anderson. 1988. Phorbol esters inhibit adenylate cyclase activity in cultured collecting tubular cells. Am. J. Physiol. 254:C183-C191. 